\title{
Diversity and endophytic fungal composition in Ananas comosus (L.) Merr. var queen cultivar isolated from three different growing conditions
}

\author{
Bhattacharya $\mathrm{S}^{1, *}$, Debnath $\mathrm{S}^{2}$ and Saha $\mathrm{AK}^{2}$ \\ ${ }^{1}$ Department of Botany, M.B.B. College, Agartala-799004, Tripura, India \\ ${ }^{2}$ Mycology and Plant Pathology Laboratory, Department of Botany, Tripura University, Suryamaninagar-799022, \\ Tripura, India
}

Bhattacharya S, Debnath S, Saha AK 2020 - Diversity and endophytic fungal composition in Ananas comosus (L.) Merr. var queen cultivar isolated from three different growing conditions. Studies in Fungi 5(1), 310-319, Doi 10.5943/sif/5/1/13

\begin{abstract}
Present study deals with the isolation of endophytic fungi from leaf and root explants of Ananus comosus var queen from three growing conditions i.e. wild, cultivated as monoculture and cultivated as mixed cropping system with rubber plants. A total of twenty-nine endophytic fungal strains along with two nonsporulating forms were isolated from the host plant from three experimental plots. The maximum numbers of fungal strains were found belong to family Aspergillaceae and order Eurotiales. The highest rates of colonization and isolation $(p<0.05)$ of endophytic fungi have been reported in wild foliar explants $(95.53 \pm 0.53)$ and monoculture $(1.02 \pm 0.01)$, respectively. The highest relative frequency was observed among isolated fungal strains in the case of Lasiodiplodia theobromae isolated from the leaf and root of wild (26.22\%) and monoculture (29.62\%) explants. In L. theobromae and Aspergillus flavus, isolated from the leaf and roots of wild (21.66\%) and monoculture (14.66\%) explants showed the highest colonization frequency. Current findings showed that the distribution of fungal endophytes and their relative frequency in host plants vary in three different growing conditions.
\end{abstract}

Key words - Colonization frequency - Fungal endophytes - Mixed cropping - Monoculture Pineapple

\section{Introduction}

Endophytes are microorganisms which colonize the living plant tissues without causing any immediate apparent harmful effects (Azevedo et al. 2000). Endophytic fungi spend whole or part of their life cycle and colonize inter and/or intracellular spaces in healthy plant tissues of stem, petiole, roots and leaves without causing no apparent symptoms of the disease (Cabral et al. 1993). According to Paulus et al. (2006), variation in chemical profiles of the host plant might affect the differential distribution of endophyte assemblages in different host plants.

Monoculture of crop plants exerts negative effects on microbial biomass and diversity. Therefore, intercropping and crop rotations are preferred for better management of soil fungi (Nayyar et al. 2009). It was suggested that different crops produce different organic residues and provide diverse food which promotes fungal diversity and activity of soil fungi (Swer et al. 2011). According to Stukenbrock \& McDonald (2008), evolutionary dynamics of host-microbe interactions shift due to environmental differences of natural and domesticated habitats and also by 
genetic variation between wild and cultivated populations of the host plant. It was stated that environmental conditions, agroecosystems and plant chemicals exert an effect on the diversity of fungal endophytic community (Saunders \& Kohn 2009). Apart from that, agricultural practices may influence root microbial communities (Seghers et al. 2004). It was reported that type of cultivation environment i.e. open fields and greenhouses affect the diversity of endophytic fungi in soybean (Pimentel et al. 2006). It was also suggested that mixed-cropping between two field pea varieties influenced root-associated microbial communities and two varieties supported significantly different fungal communities as compared to grown as monocrops (Horner et al. 2019). Moreover, extensive variation in rhizosphere composition between plant species, as well as mixedcropping between crop species can induce significant changes in soil fungal community composition and diversity ( $\mathrm{Li} \& \mathrm{Wu}$ 2018) which may affect root-associated fungal community composition.

The present study aimed to isolate endophytic fungi from leaves and roots of Ananus comosus grown under three different growing conditions i.e. wild, monoculture and as a mixed crop with Rubber. Pineapple is considered to be one of the major horticultural crops of Tripura state. Favourable agroclimatic condition favours the cultivation of this crop. Peoples even from different tribe groups have been practicing the cultivation to earn their livelihood. Two varieties of pineapple i.e. Queen and Kew variety are generally grown in the state. But Queen variety which is relatively small, rich in aromatic quality and the taste is cultivated in Sepahijala district. However, presently farmers are moving towards the rubber cultivation for high profitability. Although in some areas Pineapple being cultivated as a mixed crop with Rubber. Endophytic mycoflora is considered to be a dynamic structure which can have a role in sustainable agricultural development. This aspect certainly enhances the importance of studying endophytic fungal taxa associated with this crop under different growing conditions.

\section{Materials \& Methods}

\section{Sampling sites}

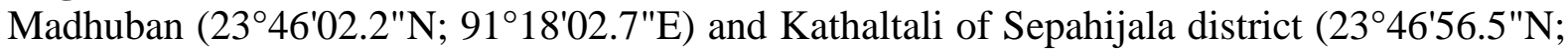
$91^{\circ} 17^{\prime 25.3 " E), ~ T r i p u r a ~ w a s ~ c h o s e n ~ a s ~ s a m p l i n g ~ s i t e ~ w h e r e ~ t h e ~ t e s t ~ s a m p l e s ~ g r o w i n g ~ u n d e r ~ t h r e e ~}$ different growing conditions i.e. at wild, cultivated (monoculture) and as cultivated (mixedcrop with rubber) and were designated as S1, S2 and S3 respectively.

\section{Sampling of explants}

A. comosus (L.) Merr.var. queen plant was selected for the present study. The plants were selected from three different growing conditions by non-random sampling method. Only healthy and disease-free plants were selected to minimize the presence of pathogenic and saprobic species. Leaves and roots were collected as explants from five host plants from three experimental sites in sterile bags and processed within 24 hours of collection. Sampling of explants was carried out from February 2013 to January 2014.

\section{Isolation of endophytic fungi}

Isolation of fungal endophytes was done according to the standard protocol (Schulz et al. 1998, Strobel \& Daisy 2003) with slight modification as per the requirement of root/leaf tissue. The exposure time length with sterilant was decided based on tissues strength. Sterilized samples were cut in the dimensions of approximately $0.5 \mathrm{~cm} \times 0.5 \mathrm{~cm}$. Four to five segments of plant tissues were placed on 2\% Malt Extract Agar (MEA) or Potato Dextrose Agar (PDA) plate supplemented with streptomycin $(100 \mu \mathrm{g} / \mathrm{ml})$, and incubated in a BOD (Biological Oxygen Demand) incubator for 7 to 21 days at $25( \pm 2)^{\circ} \mathrm{C}$. To ensure proper surface sterilization, the sterilization protocol was validated using a leaf imprint method (Schulz et al. 1998). The plated segments were monitored on every alternate day. Hyphal tips from fungi growing out from the samples were subsequently transferred onto fresh plates to isolate pure colonies. 


\section{Identification of fungi}

Macroscopic characteristics of colonies and microscopic characteristics were observed. The standard manuals and literatures were used for identification of fungi (Raper \& Fennell 1965, Booth 1971, Ellis 1971, Domsch et al. 1980, Watanabe 2002). Identification of fungal strains were authenticated by Molecular identification (ITS sequence of rDNA) or by morphological identification from NFCCI, Agharkar Research Institute, Pune. Nomenclature was authenticated from Index Fungorum (www.indexfungorum.org) and MycoBank (www.mycobank.org) databases.

\section{Data analysis}

Colonization rate (CR), Isolation rate (IR), Relative frequency (RF) (Photita et al. 2001, Huang et al. 2008) and Colonization frequency (CF) (Hata \& Futai 1995) were determined.

\section{Diversity indices}

Diversity indices were also calculated according to Hammer et al. (2001). Dominance_D, Evenness_e ${ }^{\wedge} \mathrm{H} / \mathrm{S}$, Shannon_H and Simpson_1-D and Species richness for both epiphytic and endophytic fungal strains were calculated using PAST software (3.19 version).

\section{Statistical analysis}

All the assays were performed in triplicate and the results were expressed as Mean \pm SE values. The mean values and standard error were calculated using Origin version 7.0. One way analysis of variance (ANOVA) was conducted to test the significance among the leaf or root explants of three different sampling sites. Colonization and relative frequencies of leaf and root of three types of explants (wild, monoculture and mixed cropping) using two- way ANOVA were analyzed, where the growing conditions of host plant (wild, monoculture and mixed cropping) and fungal isolates were used as factors.

\section{Results and discussion}

\section{Isolation and identification of endophytic fungi}

The present investigation deals with the comparative evaluation of endophytic fungal diversity in leaf and root explants of Pineapple (A. comosus) plant from three different growing conditions i.e. wild, monoculture, and mixedcropping. A total of twenty-nine endophytic fungal strains along with two nonsporulating forms were isolated from the host plant. Of them maximum numbers of fungal strains belong to family Aspergillaceae and order Eurotiales followed by order Hypocreales. Among the isolated endophytes, eight fungal strains and one nonsporulating form were isolated from leaf explants whereas, nine fungal strains and one nonsporulating form were obtained from root explants of host plants growing in a wild condition. From leaf explants of host plants from monoculture system ten fungal strains and one nonsporulating forms were isolated; however, from root explants, eight fungal strains and one nonsporulating form were recovered. From leaf explants of host plants grown in mixedcropping condition thirteen endophytic fungi and one nonsporulating form and from root explants twelve endophytic fungi as well as one nonsporulating form, were isolated.

Of them, Acremonium strictum was only isolated from foliar explants of S1. Daldinia eschscholtzii was isolated as leaf endophyte from S2 plants. Cladorrhinum samala, Scytalidium lignicola, Trichothecium roseum, Gongronella butleri and Monilia pruinosa were isolated from both root and leaf explants of S3. Moreover, Cladosporium cladosporioides, Nectria ventricosa and Taleromyces stollii were isolated as leaf endophyte and Mortierella zychae was isolated only from root explants in case of S3 (Table 1). It was demonstrated that mixed-cropping between two varieties of field peas alters root fungal community composition in comparison to mono-cropping (Horner et al. 2019) which partially supported the present experimental findings as here host plant A. comosus cultivated under mixedcropping system with Hevea brasiliensis. Moreover, according 
to Xiong et al. (2016) fungal communities of black pepper - vanilla and vanilla monoculture systems differed which correlated with present findings.

Table 1 Checklist of isolated endophytic fungal strains and their occurrence in explants of host plants in three growing condition.

\begin{tabular}{|c|c|c|c|c|c|c|c|c|}
\hline \multirow[t]{2}{*}{ Isolated endophytic fungal strains } & \multicolumn{2}{|c|}{ Wild (S1) } & \multicolumn{2}{|c|}{$\begin{array}{l}\text { Monoculture } \\
\text { (S2) }\end{array}$} & \multicolumn{2}{|c|}{$\begin{array}{l}\text { Mixed cropping } \\
\text { (S3) }\end{array}$} & \multirow[t]{2}{*}{ Order } & \multirow[t]{2}{*}{ Family } \\
\hline & Leaf & Root & Leaf & Root & Leaf & Root & & \\
\hline Acremonium strictum W. Gams & + & - & - & - & - & - & Hypocreales & Incertae sedis \\
\hline Aspergillus candidus Link & - & + & - & + & - & + & Eurotiales & Aspergillaceae \\
\hline Aspergillus flavus Link & - & + & - & + & - & - & Eurotiales & Aspergillaceae \\
\hline Aspergillus fumigatus Fresen. & - & - & + & - & + & - & Eurotiales & Aspergillaceae \\
\hline Aspergillus japonicus Saito & + & - & + & - & - & - & Eurotiales & Aspergillaceae \\
\hline $\begin{array}{l}\text { Cladorrhinum samala (Subram \& Lodha) W. } \\
\text { Gams \& Mouchacca }\end{array}$ & - & - & - & - & + & + & Sordariales & Podosporaceae, Lasiosphaeriaceae \\
\hline $\begin{array}{l}\text { Cladosporium cladosporioides(Fresen.) G.A. de } \\
\text { Vries }\end{array}$ & - & - & - & - & + & - & Capnodiales & Cladosporiaceae \\
\hline Curvularia lunata (Wakker) Boedijn & + & - & + & - & - & + & Pleosporales & Pleosporaceae \\
\hline Daldinia eschscholtzii (Ehrenb.) Rehm & - & - & + & - & - & - & Xylariales & Hypoxylaceae \\
\hline Fusarium oxysporum Schltdl. & - & - & + & - & + & + & Hypocreales & Nectriaceae \\
\hline Fusarium sp. & + & - & + & - & - & - & Hypocreales & Nectriaceae \\
\hline $\begin{array}{l}\text { Gongronella butleri (Lendn) Peyronel \& Dal } \\
\text { Vesco }\end{array}$ & - & - & - & - & + & + & Mucorales & Cunninghamellaceae \\
\hline $\begin{array}{l}\text { Lasiodiplodia theobromae (Pat.) Griffon \& } \\
\text { Maubl. }\end{array}$ & + & + & + & + & - & + & Botryosphaeriales & Botryosphaeriaceae \\
\hline Monilia pruinosa Cooke \& Massee & - & - & - & - & + & + & Helotiales & Sclerotiniaceae \\
\hline Mortierella zychae Linnem. & - & - & - & - & - & + & Mortierellales & Mortierellaceae \\
\hline Nectria ventricosa C. Booth & - & - & - & - & + & - & Hypocreales & Nectriaceae \\
\hline Nigrospora oryzae (Berk. \& Broome) Petch & + & - & + & - & - & - & Xylariales & Apiosporaceae \\
\hline Paecilomyces variotii Bainier & - & + & - & + & - & + & Eurotiales & Thermoascaceae \\
\hline Penicillium citrinum Thom & - & - & + & - & + & - & Eurotiales & Aspergillaceae \\
\hline Penicillium sclerotiorum J.F.H. Beyma & + & + & + & + & - & - & Eurotiales & Aspergillaceae \\
\hline Pestalotiopsis versicolor (Speg.) Steyaert & + & - & + & + & + & + & Amphisphaeriales & Pestalotiopsidaceae \\
\hline Rhizoctonia solani J.G. Kühn & - & + & - & + & - & - & Cantharellales & Ceratobasidiaceae \\
\hline Scytalidium lignicola Pesante & - & - & - & - & + & + & Helotiales & Hyaloscyphaceae \\
\hline $\begin{array}{l}\text { Staphylotrichum coccosporum J.A. Mey. \& } \\
\text { Nicot }\end{array}$ & - & - & - & - & + & - & Incertae sedis & Not assigned \\
\hline $\begin{array}{l}\text { Talaromyces stollii N. Yilmaz, Houbraken, } \\
\text { Frisvad \& Samson }\end{array}$ & - & + & - & - & + & - & Eurotiales & Trichocomaceae \\
\hline Trichoderma harzianum Rifai & - & + & - & + & - & - & Hypocreales & Hyросreaceae \\
\hline
\end{tabular}


Table 1 Continued.

\begin{tabular}{|c|c|c|c|c|c|c|c|c|}
\hline \multirow[t]{2}{*}{ Isolated endophytic fungal strains } & \multicolumn{2}{|c|}{ Wild (S1) } & \multicolumn{2}{|c|}{$\begin{array}{c}\begin{array}{c}\text { Monoculture } \\
\text { (S2) }\end{array} \\
\end{array}$} & \multicolumn{2}{|c|}{$\begin{array}{l}\text { Mixed cropping } \\
\text { (S3) }\end{array}$} & \multirow[t]{2}{*}{ Order } & \multirow[t]{2}{*}{ Family } \\
\hline & Leaf & Root & Leaf & Root & Leaf & Root & & \\
\hline Trichothecium roseum (Pers.) Link & - & + & - & - & + & + & Hypocreales & Incertae sedis \\
\hline Nonsporulating hyaline form & + & - & + & - & - & - & Not applicable & Not applicable \\
\hline Nonsporulating dematitious form & - & + & - & + & + & + & Not applicable & Not applicable \\
\hline
\end{tabular}

Different fungal strains were reported to be isolated as endophytes from different host plants. Aspergillus japonicus was isolated from Tridax procumbens (Aharwal et al. 2018), Aspergillus fumigatus and Nigrospora oryzae were from Eucalyptus citriodora (Kharwar et al. 2010) and Aspergillus flavus and Penicillum citrinum were reported from medicinal plants (Uma Maheswari \& Saranya 2018). Whereas, Cladosporium cladosporioides and Trichoderma harzianum were recovered from Quercus sp. (Moricca et al. 2012), Acremonium strictum were isolated from tea cultivars (Win et al. 2017), Lasiodiplodia theobromae was reported from Catharanthus roseus (Dhayanithy et al. 2019) and Penicillium sclerotiorum was isolated from Garcinia atroviridis (Arunpanichlert et al. 2010). Moreover, Talaromyces sp., Curvularia lunata and Fusarium oxysporum were isolated from medicinal herbs (Rajagopal et al. 2010), Rhizoctonia solani was reported from wheat plant (Comby et al. 2016), Staphylotrichum coccosporum was identified from Coscinium fenestratum (Goveas et al. 2011) and Monilia sp. Mortierella sp. were isolated from Aquilaria sinensis. (Gong \& Guo 2009) In the present investigation, these fungal strains were isolated as foliar and/or root endophytes from the host plants grown in three sampling sites. As low host preference or host specificity of endophytic fungi was observed in previous investigations (Cannon \& Simmons 2002, Rajamani et al. 2018), it might be possible that isolated endophytes from the host plant $A$. comosus overlap with isolated endophytic fungal strains from other host plants. Sterile forms were also isolated from many other angiospermic hosts (Cannon \& Simmons 2002) which correlated with present findings where two types of nonsporulating forms were isolated as endophytes. Pestalotiopsis sp. and Fusarium sp. were reported as endophytes of Hevea brasiliensis (Rocha et al. 2011). Moreover, Cladosporium cladosporioides, Lasiodiplodia theobromae, Trichoderma harzianum, Pestalotiopsis sp. and Fusarium sp. were isolated as endophytes from Hevea brasiliensis (Gazis \& Chaverri 2010). These endophytic fungal strains were also obtained from explants sampled from host plant growing with $H$. brasiliensis in the present investigation. Fusarium oxysporum and Pestalotiopsis versicolor were documented as endophytes from explants of host plant grown under mixedcropping system with Hevea brasiliensis in present experimental findings. Wearn et al. (2012) stated that the isolated endophytes showed organ specificity within plants. The present experimental findings also indicated that some of the isolated endophytes showed organ specificity and species number and diversity of endophyte also varied between leaf and root explants (Table 1). Huang et al. (2008) also indicated the tissue specific nature of endophytic fungi although most of the endophytes only exhibited tissue preference.

\section{Analysis of diversity}

To find out the significant effect of colonization and isolation rate of explants (Table 2) on two types of explants i.e. leaf and root sampled from wild, monoculture and mixed cropping conditions the analysis of variance (ANOVA One Way) was performed. Thus, if the significant effect of at least one explant sample had been found at $5 \%$ level of significance (i.e., $p$-value $<0.05$ ), then Tukey HSD test was carried out to identify the presence 
of most significant effects of colonization and isolation rate in which explants. The $p$-value of corresponding ANOVA (One Way) had been reported $(<0.05)$ in Table 2. The highest colonization and isolation rates of endophytic fungi were recorded in foliar explants of wild (95.53 \pm 0.53$)$ and monoculture (1.02 \pm 0.01$)$ respectively and both of them were showed significant differences $(p<0.05)$ from others. Whereas for root and leaf explants of wild types the lowest colonization and isolation levels of endophytes were observed, and they also showed a significant difference at $p<0.05$ from other types.

Table 2 Colonization and isolation rate in different explants (S1, S2 and S3) collected from three sampling sites.

\begin{tabular}{cccccc}
\hline \multirow{2}{*}{ Colonisation and isolation rate } & \multicolumn{3}{c}{ Sampling sites } & \multirow{2}{*}{ p-value } \\
\cline { 2 - 5 } & of explants & Wild (S1) & Monoculture (S2) & Mixed cropping (S3) & \\
\hline \multirow{2}{*}{ Leaf } & colonization Rate & $95.53 \pm 0.53 \mathrm{a}$ & $87.22 \pm 0.56 \mathrm{~b}$ & $83.89 \pm 0.56 \mathrm{c}$ & $1.47 \mathrm{E}-05$ \\
& Isolation Rate & $0.87 \pm 0.01 \mathrm{a}$ & $1.02 \pm 0.01 \mathrm{~b}$ & $0.97 \pm 0.01 \mathrm{c}$ & $8.93 \mathrm{E}-06$ \\
\hline \multirow{2}{*}{ Root } & colonization Rate & $78.89 \pm 1.11 \mathrm{a}$ & $93.67 \pm 1.83 \mathrm{~b}$ & $80.55 \pm 0.55 \mathrm{a}$ & 0.00033 \\
& Isolation rate & $0.96 \pm 0.01 \mathrm{a}$ & $0.95 \pm 0.00 \mathrm{a}$ & $0.93 \pm 0.01 \mathrm{a}$ & 0.085 \\
\hline
\end{tabular}

Each value is expressed as the mean \pm SE of three replicates. Different alphabets differ significantly at $p<0.05$ along with each sampling sites.

Among isolated fungal strains, the highest relative frequency was observed in the case of Lasiodiplodia theobromae isolated from leaf and root of S1 and root explants of S2 (Table 3). Daldinia escholtzii, exhibited the highest relative frequency in foliar explants of S2. For S3 explants highest relative frequency was observed in Taleromyces stollii (leaf explant) and Aspergillus candidus (root explant). Colonization frequency of different fungal strains also varied (Table 3).The colonization and relative frequencies of isolated fungi from root significantly differed between three sampling sites (wild, monoculture and mixed cropping) (isolates: $F=4.95$, $p<0.001$ and $\mathrm{F}=4.33, p<0.001$ ), whereas colonization and relative frequencies of endophytic fungi in foliar explants showed no significant differences between three growing conditions. The result may be interpreted with earlier finding where Treatment group (mono-cropped and mixed-cropped) significantly affect root fungal community composition in two field pea varieties (Horner et al. 2019).

The similarity of endophytic fungal strains isolated from explants of different sampling sites might be supported by the fact that the genetic correlation of the host plant determines the extent of similarity of endophyte communities (Sieber 2007). It was suggested that the variation in colonization pattern and diversity of endophytic fungi in roots of plants of Chenopodiaceae family might be due to difference in phytogeography and soil condition (Aletaha et al. 2018). Differences in colonization and occurrence of endophytic fungi of roots from different sampling sites recorded in the present study also correlated and interpreted with these findings. Colonization frequency of different endophytic fungi colonized varied in different plant tissues. This might be due to the differential affinity of each endophyte to different plant tissues (Dhayanithy et al. 2019). It was stated that change in microbial communities may be due to different plant exudates produced under the mixed-cropping regime in comparison to mono-cropping in field pea varieties (Horner et al. 2019). Endophytic fungal composition in the present investigation also varied between different explants collected from three sampling sites which might be substantiated by the earlier finding. The present finding was also supported by earlier finding where the distribution of the fungal species within the host differed in different microhabitat (Putra et al. 2015).

The highest and lowest value of Shannon and Simpson diversity indices were observed in leaf explants of S3 and S1 respectively (Table 4). Whereas, highest and lowest evenness value was recorded in case of S1 root and S1 leaf respectively. The maximum value of dominance was recorded in case of S1 leaf (Table 4). Species richness was greater in leaf explants than root in case of endophytic fungal assemblages which correlated with earlier finding (Sahani \& Hemalatha 2018). 
Table 3 Colonization frequency and relative frequency of isolated fungal endophytes.

\begin{tabular}{|c|c|c|c|c|c|c|c|c|c|c|c|c|}
\hline \multirow{2}{*}{ Name of the fungal strains } & \multicolumn{3}{|c|}{ CF (\%) of Leaf } & \multicolumn{3}{|c|}{ RF (\%) of Leaf } & \multicolumn{3}{|c|}{ CF (\%) of Root } & \multicolumn{3}{|c|}{ RF (\%) of Root } \\
\hline & S1 & S2 & S3 & S1 & S2 & S3 & S1 & S2 & S3 & S1 & $\mathrm{S} 2$ & S3 \\
\hline Acremonium strictum & 3.33 & 0 & 0 & 3.27 & 0 & 0 & 0 & 0 & 0 & 0 & 0 & 0 \\
\hline Aspergillus candidus & 0 & 0 & 0 & 0 & 0 & 0 & 6.66 & 8.33 & 12.33 & 5.3 & 11.25 & 17.41 \\
\hline Aspergillus flavus & 0 & 0 & 0 & 0 & 0 & 0 & 8.33 & 14.66 & 0 & 8.19 & 25 & 0 \\
\hline Aspergillus fumigatus & 0 & 11.66 & 10.66 & 0 & 9.65 & 12.24 & 0 & 0 & 0 & 0 & 0 & 0 \\
\hline Aspergillus japonicus & 8.33 & 3.33 & 0 & 8.19 & 4.83 & 0 & 0 & 0 & 0 & 0 & 0 & 0 \\
\hline Cladorrhinum samala & 0 & 0 & 5 & 0 & 0 & 5.66 & 0 & 0 & 6.66 & 0 & 0 & 8.43 \\
\hline Cladosporium cladosporoides & 0 & 0 & 8.66 & 0 & 0 & 9.34 & 0 & 0 & 0 & 0 & 0 & 0 \\
\hline Curvularia lunata & 8.35 & 5 & 0 & 11.47 & 6.45 & 0 & 0 & 0 & 6.66 & 0 & 0 & 8.43 \\
\hline Daldinia escholtzii & 0 & 16.66 & 0 & 0 & 20.12 & 0 & 0 & 0 & 0 & 0 & 0 & 0 \\
\hline Fusarium oxysporum & 0 & 8.33 & 10 & 0 & 9.9 & 10.79 & 0 & 0 & 3.66 & 0 & 0 & 4.33 \\
\hline Fusarium sp. & 8.33 & 5 & 0 & 10.33 & 4.83 & 0 & 0 & 0 & 0 & 0 & 0 & 0 \\
\hline Gongronella butleri & 0 & 0 & 3.66 & 0 & 0 & 5.17 & 0 & 0 & 5 & 0 & 0 & 5.66 \\
\hline Lasiodiplodia theobromae & 21.66 & 10 & 0 & 26.22 & 11.95 & 0 & 11.33 & 16.33 & 11.66 & 18.95 & 29.62 & 16.86 \\
\hline Monilia pruinosa & 0 & 0 & 3.66 & 0 & 0 & 5.17 & 0 & 0 & 3.66 & 0 & 0 & 3.44 \\
\hline Mortierella zychae & 0 & 0 & 0 & 0 & 0 & 0 & 0 & 0 & 3.66 & 0 & 0 & 4.19 \\
\hline Nectria ventricosa & 0 & 0 & 6.66 & 0 & 0 & 5.66 & 0 & 0 & 0 & 0 & 0 & 0 \\
\hline Nigrospora oryzae & 14.9 & 3.33 & 0 & 12.33 & 4.83 & 0 & 0 & 0 & 0 & 0 & 0 & 0 \\
\hline Paecilomyces variotii & 0 & 0 & 0 & 0 & 0 & 0 & 16.66 & 13.66 & 10 & 11.47 & 14.95 & 9.43 \\
\hline Penicillium citrinum & 0 & 5 & 6.66 & 0 & 6.05 & 9.34 & 0 & 0 & 0 & 0 & 0 & 0 \\
\hline Penicillium sclerotiorum & 16.66 & 12.33 & 0 & 18.22 & 14.1 & 0 & 10 & 8.33 & 0 & 15.47 & 14.87 & 0 \\
\hline Pestalotiopsis versicolor & 6.66 & 3.33 & 3.66 & 6.55 & 3.22 & 3.44 & 0 & 10 & 6.66 & 0 & 12 & 10 \\
\hline Rhizoctonia solani & 0 & 0 & 0 & 0 & 0 & 0 & 5 & 8.33 & 0 & 9.66 & 9.25 & 0 \\
\hline Scytallidium lignicola & 0 & 0 & 3.66 & 0 & 0 & 3.44 & 0 & 0 & 3.66 & 0 & 0 & 4.66 \\
\hline Staphylotrichum coccosporum & 0 & 0 & 3.33 & 0 & 0 & 3.44 & 0 & 0 & 0 & 0 & 0 & 0 \\
\hline Taleromyces stollii & 0 & 0 & 12.33 & 0 & 0 & 18.58 & 10 & 0 & 0 & 9.83 & 0 & 0 \\
\hline Trichoderma harzianum & 0 & 0 & 0 & 0 & 0 & 0 & 5 & 8.33 & 3.66 & 8.91 & 11.66 & 4.33 \\
\hline Trichothecium roseum & 0 & 0 & 3.33 & 0 & 0 & 3.44 & 3.33 & 0 & 0 & 6.55 & 0 & 0 \\
\hline Nonsporulating hyaline form & 6.66 & 3.33 & 0 & 3.27 & 3.22 & 0 & 0 & 0 & 0 & 0 & 0 & 0 \\
\hline Nonsporulating dematitious form & 0 & 0 & 3.33 & 0 & 0 & 3.44 & 3.33 & 3.33 & 3.33 & 4.91 & 7.45 & 2.19 \\
\hline
\end{tabular}

Note: Wild (S1), Monoculture (S2), Mixedcropping (S3), Colonization frequency (CF) and Relative frequency (RF) 
Table 4 Analysis of the diversity of fungal isolates from A. comosus.

Note: Wild (S1), Monoculture (S2) and Mixedcropping (S3)

\begin{tabular}{lcccccc}
\hline Diversity indices & S1 leaf & S1 root & S2 leaf & S2 root & S3 leaf & S3 root \\
\hline Taxa_S & 9 & 10 & 12 & 9 & 14 & 13 \\
Dominance_D & 0.1546 & 0.1179 & 0.1126 & 0.1348 & 0.09792 & 0.1057 \\
Simpson_1-D & 0.8454 & 0.8821 & 0.8874 & 0.8652 & 0.9021 & 0.8943 \\
Shannon_H & 2.011 & 2.218 & 2.325 & 2.101 & 2.476 & 2.393 \\
Evenness_e^H/S & 0.83 & 0.9189 & 0.8526 & 0.9078 & 0.85 & 0.8422 \\
\hline
\end{tabular}

\section{Conclusion}

The colonization and relative frequencies isolated fungi from root significantly differed between wild, monoculture and mixed cropping regimes. Mixed-cropping between Pineapple and Rubber plant might direct to changes in fungal community composition of roots differently. This in turn pointed to changes in soil chemistry and microbial interactions. Different cropping management system might be helpful for isolating newer fungal taxa. More number of fungal taxa recovered from explants of mixed cropping system, which might indicate the preference of mixed cropping system over monoculture. However, extensive sampling from different sites is required in this respect. Further, isolated endophytic fungal strains may be evaluated for antagonistic activity against plant pathogen of host plant as well as mixed crop.

\section{Acknowledgements}

The authors are grateful to the Head, Department of Botany, Tripura University for providing all sorts of facilities. The authors are grateful to NFCCI, Agharkar Research Institute, Pune, India especially Dr. S.K. Singh and Dr. A. Baghela for providing valuable assistance in identification of fungal strains.

\section{Conflict of interest statement}

The authors declare that they have no competing interests.

\section{Funding statement Nil.}

\section{References}

Aharwal RP, Kumar S, Thakur Y, Deshmukh L, Sandhu SS. 2018 - Evaluation ofantibacterial activity of endophytic fungi Aspergillus japonicus isolated from Tridax Procumbens L. Asian Journal of Pharmaceutical and Clinical Research 11(9), 212-216.

Aletaha R, Safari Sinegani AA, Zafari D. 2018 - A survey on the endophytic fungi in the roots of Chenopodiaceae under different environmental conditions. Mycosphere 9(4), 618-634.

Doi: 10.5943/mycosphere/9/4/1

Arunpanichlert J, Rukachaisirikul V, Sukpondma Y, Phongpaichit S et al. 2010 - Azaphilone and isocoumarin derivatives from the endophytic fungus Penicillium sclerotiorum PSU-A13. Chemical and Pharmaceutical Bulletin 58(8), 1033-1036.

Azevedo Jl, Maccheroni WJR, Pereira JO, Araújo WL. 2000 - Endophytic microrganisms: a review on insect control and recent advances tropical plants. Electronic Journal of Biotechnology 3, 40-65.

Booth C. 1971 - The genus Fusarium. Commonwealth Mycological Institute, Kew, Surrey, United Kingdom.

Cabral D, Stone J, Carroll GC. 1993 - The internal mycoflora of Juncus spp. microscopic and cultural observation of infection patterns. Mycological Research 97, 367-376.

Cannon PF, Simmons CM. 2002 - Diversity and host preference of leaf endophytic fungi in the Iwokrama Forest Reserve, Guyana. Mycologia 94(2), 210-220. 
Comby M, Lacoste S, Baillieul F, Profizi C, Dupont J. 2016 - Spatial and temporal variation of cultivable communities of co-occurring endophytes and pathogens in wheat. Frontiers in Microbiology 7, 403. Doi: 10.3389/fmicb.2016.00403

Dhayanithy G, Subban K, Chelliah J. 2019 - Diversity and biological activities of endophytic fungi associated with Catharanthus roseus. BMC Microbiology 19, 22.

Doi: 10.1186/s12866-019-1386-X.

Domsch KH, Gams W, Anderson TH. 1980 - Compendium of soil fungi Vol.1. Academic Press (London) Ltd.

Ellis MB. 1971 - Dematiaceous hypomycetes. CAB International.

Gazis R, Chaverri P. 2010 - Diversity of fungal endophytes in leaves and stems of wild rubber trees (Hevea brasiliensis) in Peru. Fungal Ecology 3, 240-254.

Gong LJ, Guo SX. 2009 - Endophytic fungi from Dracaena cambodiana and Aquilaria sinensis and their antimicrobial activity. African Journal of Biotechnology 8(5), 731-736

Goveas SW, Madtha R, Nivas SK, D’Souza L. 2011 - Isolation of endophytic fungi from Coscinium fenestratum (Gaertn.) Colber. a red listed endangered medicinal plant. Bulgarian Journal of Agricultural Science 17, 767-772.

Hammer Ø, Harper DAT, Ryan PD. 2001 - PAST: Paleontological statistics software package for education and data analysis. Palaeontologia Electronica 4, 1-9.

Hata F, Futai K. 1995 - Endophytic fungi associated with healthy pine needles and needles infested by pine needle gall midge Thecodiplosis japonensis. Canadian Journal of Botany 73, 384390.

Horner A, Browett SS, Antwis RE. 2019 - Mixed cropping between fields Pea varieties alters root bacterial and fungal communities. Scientific Reports 9, 16953.

Doi: 10.1038/s41598-019-53342-8

Huang WY, Cai YZ, Hyde KD, Corke H, Sun M. 2008 - Biodiversity of endophytic fungi associated with 29 traditional Chinese medicinal plants. Fungal Diversity 33, 61-75.

Kharwar RN, Gond SK, Kumar A, Mishra A. 2010 - A comparative study of endophytic and epiphytic fungal association with leaf of Eucalyptus citriodora Hook., and their antimicrobial activity. World Journal of Microbiology \& Biotechnology 26, 1941-1948.

Li S, Wu F. 2018 - Diversity and co-occurrence patterns of soil bacterial and fungal communities in seven intercropping systems. Frontiers in Microbiology 9, 1-13.

Moricca S, Ginetti B, Ragazzi A. 2012 - Species- and organ-specificity in endophytes colonizing healthy and declining Mediterranean oaks. Phytopathologia Mediterranea 51(3), 587-598.

Nayyar A, Hamel C, Lafond G, Gossen BD et al. 2009 - Soil microbial quality associated with yield reduction in continuous-pea. Applied Soil Ecology 43(1), 115-121.

Paulus B, Kanowski J, Gadek P, Hyde KD. 2006 - Diversity and distribution of saprobic micro fungi in leaf litter of an Australian tropical, rainforest. Mycological Research 110, 14411454.

Photita W, Lumyoug S, Lumyoug P, Hyde KD. 2001 - Endophytic fungi of wild banana (Musa acuminate) at Doi Suthep Pui National Park, Thailand. Mycological Research 105, 15081513.

Pimentel IC, Glienke-Blanco C, Gabardo J, Stuart RM, Azevedo JL. 2006 - Identification and colonization of endophytic fungi from soybean (Glycine max (L.) Merril) under different environmental conditions. Brazilian Archives of Biology and Technology 49(5), 705-11.

Putra IP, Rahayu G, Hidayat I. 2015 - Impact of Domestication on the endophytic fungal diversity associated with wild zingiberaceae at Mount Halimun Salak National Park. Hayati Journal of Biosciences 22, 157-162.

Rajagopal K, Kalavathy S, Kokila S, Karthikeyan S et al. 2010 - Diversity of fungal endophytes in few medicinal herbs of South India. Asian Journal of Experimental Biological Sciences 1(2), 415-418. 
Rajamani T, Suryanarayanan TS, Murali TS, Thirunavukkarasu N. 2018 - Distribution and diversity of foliar endophytic fungi in the mangroves of Andaman Islands, India. Fungal Ecology 36, 109-116.

Raper KB, Fennell PI. 1965 - The genus Aspergillus. Williams and Wilkins, Baltimore, U.S.A.

Rocha ACS, Garcia D, Uetanabaro APT, Carneiro RTO et al. 2011 - Foliar endophytic fungi from Hevea brasiliensis and their antagonism on Microcyclus ulei. Fungal Diversity 47, 75-84.

Sahani K, Hemalatha KPJ. 2018 - Diversity of endophytic fungi from Tribulus terrestris L. from Eastern Ghat of India (First Report). International Journal of Pharmaceutical Sciences Review and Research 50(1), 197-206.

Saunders M, Kohn LM. 2009 - Evidence for alteration of fungal endophyte community assembly by host defense compounds. New Phytologist 182, 229-38.

Schulz B, Guske S, Damman U, Boyle C. 1998 - Endophyte host interaction II: Defining symbiosis of endophyte host innteraction. Symbiosis 25: 212-227.

Sieber TN. 2007 - Endophytic fungi in forest trees: are they mutualists?. Fungal Biology Reviews 21, 75-89.

Seghers D, Wittebolle L, Top EM, Verstraete W, Siciliano S. 2004 - Impact of agricultural practices on the Zea mays L. endophytic community. Applied and Environmental Microbiology 70, 1475-1482.

Strobel G, Daisy B. 2003 - Bioprospecting for microbial endophytes and their natural products. Microbiology and Molecular Biology Reviews 67(4), 491-502.

Stukenbrock EH, McDonald BA. 2008 - The origins of plant pathogens in agro-ecosystems. Annual Review of Phytopathology 46, 75-100.

Swer H, Dkhar, MS, Kayang H. 2011 - Fungal population and diversity in organically amended agricultural soils of Meghalaya, India. Journal of Organic Systems 6(2), 3-12.

Uma Maheswari N, Saranya P. 2018 - Isolation and identification and phytochemical screening of endophytes from medicinal plants. International Journal of Biology Research 3(1), 16-24.

Watanabe T. 2002 - Pictorial Atlas of soil and seed fungi: morpholologies of cultured fungi and key to species. $2^{\text {nd }}$ ed. CRC Press Florida US.

Wearn JA, Sutton BC, Morley NJ, Gange AC. 2012 - Species and organ specificity of fungal endophytes in herbaceous grassland plants. Journal of Ecology100, 1085-1092.

Win PM, Matsumura E, Fukuda K. 2017 - Diversity of tea endophytic fungi: cultivar- and tissue preferences. Applied Ecology and Environmental Research 16(1), 677-695.

Xiong W, Zhao Q, Xue C, Xun W et al. 2016 - Comparison of fungal community in black peppervanilla and vanilla monoculture systems associated with vanilla Fusarium wilt disease. Frontiers in Microbiology 7, 1-8. 